\title{
Typologia reżimów hybrydalnych. Ujęcie teoretyczno-metodologiczne
}

\section{Typology of Hybrid Regimes. Theoretical and Methodological Aspect}

\section{- Abstrakt •}

Artykuł porusza teoretyczne i metodologiczne aspekty badań nad reżimami hybrydalnymi, które znajdują się między demokracją a autorytaryzmem. Celem artykułu było zaprezentowanie i zbudowanie typologii reżimów hybrydalnych. Realizacja celu obejmowała dwa etapy. $\mathrm{Na}$ pierwszym etapie dokonano operacjonalizacji kategorii typologii i zaprojektowano schemat jej konstrukcji, na podstawie schematu budowy skali pomiarowej. Na drugim etapie zaprojektowany schemat konstrukcji typologii został zastosowany w tworzeniu typologii reżimów hybrydalnych.

Słowa kluczowe: reżimy hybrydalne, demokracja, autorytaryzm, tranzycja systemowa typologia, klasyfikacja

\section{- Abstract •}

In the article the author raises the issues of theoretical and methodological aspects of research studies on hybrid regimes being a combination of democracy and authoritarianism. The aim of the research was to present and develop a typology of hybrid regimes. The implementation consisted of two stages. At the first stage the operationalisation of category of typology was developed and the structure schema of its construction was planned. At the second stage the planned structure schema of typology construction was applied in the creation to typology of hybrid regimes.

Keywords: hybrid regimes, democracy, authoritarianism, system transition typology, classification

\section{Wstęp}

Proces tranzycji systemowej poruszany w kontekście przekształcania się reżimów autorytarnych w demokratyczne oraz kwestia częściowego braku skutecznego zakończenia procesów tranzycyjnych niejednokrotnie były tematem prac polskich i zagranicznych badaczy. Pomimo zainteresowania problematyką, nie została ona w pełni wyczerpana. Larry Daimond (1996), konstatując koniec procesu „trzeciej 
fali demokratyzacji”, zauważył powstanie nowego zjawiska: niektóre państwa nie przekształcały się w demokracje liberalne, a osiągały tzw. stany pośrednie reżimów politycznych znajdujących się pomiędzy demokracją a autorytaryzmem. Z kolei Marcel H. Van Herpen, dokonując analizy systemu politycznego Rosji, podkreśla, że w niektórych przypadkach trudno jest dokonać klasyfikacji państwa jako konkretnego reżimu. Posługiwanie się określeniami „demokratyczny” i „niedemokratyczny" nie jest jednoznaczne. W jego ujęciu zastosowanie pojęcia reżimu niedemokratycznego „może to nam mówić o tym, że proces demokratyzacji chwilowo się zatrzymał, ale jest nadzieja, że zostanie on wznowiony. Może być tak że proces demokratyzacji zatrzymał się definitywnie, a dość sztywny reżim autokratyczny znalazł sobie miejsce w szarej strefie pomiędzy demokracją a represyjną dyktaturą. Trzecia możliwość jest taka, że Rosja idzie w przeciwnym kierunku i oddala się coraz bardziej od ideałów demokracji i rządów prawa, wciąż wzmacniając tendencje autokratyczne" (Van Herpen, 2014, s. 141-142). Z kolei Andrzej Antoszewski podkreśla, że „nawet państwa uznawane za skonsolidowane demokracje postkomunistyczne nie są wolne od autorytarnych zagrożeń wynikających z ułomności rozwiązań instytucjonalnych lub praktyki politycznej" (Antoszewski, 2014, s. 7).

Wraz z rozwojem badań dotyczących procesów tranzycji systemowej pojawiła się kategoria reżimów hybrydalnych, na specyfikę której składają się uwarunkowania procesu tranzycji systemowej (gdy państwo odrzuca cechy starego reżimu i określa nowe zasady funkcjonowania). W badaniach nad reżimami pojawiają się wobec tego istotne pytania, wśród których można wyodrębnić kilka ważnych kwestii: 1) Czy reżimy hybrydalne należy traktować tylko i wyłącznie jako etap tranzycji systemowej?; 2) jak określać/kategoryzować reżimy, gdy proces przekształcenia jest długi, a istnieją przesłanki do stwierdzenia, że państwo skonsolidowało się na etapie przejściowym, a także nie występują wyraźne dążenia do zmiany reżimu politycznego?; 3) czy w takim przypadku właściwym będzie określanie państw znajdujących się na opisanym etapie jako kolejnych stadiów tranzycji systemowej, nie zaś odrębnych reżimów hybrydalnych?

Celem artykułu jest zbudowanie i zaprezentowanie typologii reżimów hybrydalnych. W tym przypadku konieczne jest wprowadzenie jasnych kryteriów pozwalających na rozgraniczenia reżimów hybrydalnych jako stanu tymczasowego (kolejny etap tranzycji) lub jako stanu stałego ${ }^{1}$ (dokonanie konsolidacji reżimu hybrydalnego).

${ }^{1}$ Posługuję się tym określeniem w celu rozgraniczenia reżimów hybrydalnych. 


\section{Klasyfikacja a typologia - ujęcie porównawcze}

Nie ma wątpliwości, że stworzenie typologii i/lub klasyfikacji kategorii teoretycznej nie jest zadaniem łatwym. Wymaga od twórcy zarówno wiedzy na temat analizowanego zjawiska, jak i wiedzy z zakresu metodologii. Nie jest możliwe dokonanie odpowiedniej typologizacji czy klasyfikacji bez znajomości konstrukcji ich schematu. Istotny w tym przypadku jest nie tylko sam fakt dokonania rodzajowej segregacji zjawisk, pojęć czy kategorii (czyli dokonanie podziału usystematyzowanego ze względu na pewne kryteria), lecz przede wszystkim weryfikacja, czy skonstruowana typologia jest logicznie poprawna, zatem warunkiem koniecznym było dokonanie walidacji typologii.

Warto zaznaczyć, że pojęcia typologii nie należy postrzegać jako tożsamego z terminem klasyfikacji. Tomasz Rzepiński (2016) zwraca uwagę, że w literaturze przedmiotu stosunek typologii do klasyfikacji prezentuje się niezgodnie. Niektórzy badacze uznają, że typologia nie musi spełniać rygorystycznych warunków wymaganych w przypadku klasyfikacji (Nawrot, 2012). Inni natomiast podkreślają, że cecha, która je różnicuje to uporządkowany charakter pojęć typologicznych, którego nie posiadają pojęcia klasyfikujące (Pawłowski, 1977; Kagan, 1977; Kondakow, 1975).

W związku z tą rozbieżnością koniecznym jest przeanalizowanie pojęć klasyfikacji oraz typologii. Klasyfikacja zakłada przypisanie analizowanych obiektów do odpowiednich klas na podstawie cech tych obiektów. Podział obiektów dokonywany jest na podstawie pewnej zmiennej, a ich wyróżnione wartości tworzą schemat klasyfikacji, który umożliwia podział na klasy. Najczęściej używanym, a zarazem najprostszym schematem klasyfikacji, jest dychotomia, która zakłada rozgraniczenia na klasy tych, którzy posiadają daną cechę i tych, którzy jej nie posiadają, np. społeczeństwo możemy pogrupować na tych, którzy mają ukończone 18 lat (są pełnoletni) oraz tych, którzy jeszcze nie osiągnęli tego wieku (uznaje się ich za nieletnich) (Nowak, 2007, s. 158). Możliwe jest także tworzenie złożonych klasyfikacji, szczególnie wtedy, gdy człony klasyfikacji poddamy dalszym podziałom i w efekcie uzyskamy klasyfikację dwustopniową, z klasyfikacji dwustopniowej trzystopniową itd. W przypadku schematu klasyfikacyjnego musi on spełniać dwa warunki: po pierwsze być wyczerpujący, co znaczy, że każdy obiekt objęty klasyfikacją musi być przypisany do którejś z klas (nie istnieją obiekty, które nie są przypisane do żadnej z nich), po drugie być rozłączny, co sprowadza się do tego, że jeden i ten sam obiekt nie może być przypisany do więcej niż jednej klasy. Czynność klasyfikowania kategorii poszczególnych zmiennych jest działaniem o cha- 
rakterze jakościowym, które jest podporządkowane potrzebom danego badania (zob. Nowak, 2007; Saran, 2014; Andreekowa, Tolstowoj, 1982).

Typologia z kolei zakłada podział pewnych obiektów, w naszym przypadku kategorii, na grupy (rodzaje), ze względu na jedną wspólną cechę lub grupę cech, które stanowią pewien typ. Typologizacja to czynność wyboru w danym szeregu członów systematyzacji oraz członów granicznych i zsumowanie ich razem z członami znajdującymi się między członami granicznymi. Uzyskana suma określana jest jako typ, pojęcie oznaczające pewne zjawisko, własność lub konfigurację zjawisk czy własności rozważanych przedmiotów, zdarzeń lub procesów (Nowak, 2007, s. 161). Podział typologiczny jest bardziej elastyczny aniżeli klasyfikacja, ponieważ nie musi spełniać wcześniej wspomnianych cech wyczerpalności i rozłączności, gdzie niektóre elementy mogą wykazywać cechy mieszane i nie da się ich jednocześnie przypisać do określonego typu. Jego stosowanie jest uzasadnione $\mathrm{w}$ sytuacjach, gdy użycie klasyfikacji byłoby mało czytelne $\mathrm{w}$ analizie ze względu na zbyt rozbudowaną strukturę. O ile klasyfikacja, w szczególności wielowymiarowa, mnoży liczbę klas wyróżnionych, to w przypadku typologii celem jest zredukowanie ich liczby, a zatem typologia pozwala na dokonanie bardziej zwartej segmentacji typów (Zob. Andreekowa, Tolstowoj, 1982; Dawydczenko, 2006; Moskwitin, 2001).

T. Rzepiński podkreśla, że konstruowanie typologii związane jest z przekształceniem skal pomiarowych. Zatem skale ilościowe, które charakteryzują się wysokim stopniem dokładności zostają przekształcone w mniej dokładne skale o charakterze jakościowym. Decyzja o przekształceniu skal ma charakter arbitralny, w związku z czym Rzepiński doszukuje się rozgraniczenia między typologią a klasyfikacją o arbitralnym charakterze przyjmowanym przez badacza w procesie przekształcenia skal pomiarowych. Klasyfikacja jednostopniowa umożliwia pogrupowanie obiektów, które nie są nieodróżnialne ze względu na minimum jeden atrybut. W przypadku typologii grupowanie przedmiotów następuje z uwagi na arbitralną decyzję badacza podjętą na podstawie ich podobieństw. Grupowanie przedmiotów zatem oznacza wyodrębnienie ich typów. Arbitralną staje się ocena tego, jaki stopień wzajemnego podobieństwa występuje między podmiotami, co pozwala zgrupować je w określone typy (Rzepiński, 2016, s. 200-206).

Biorąc pod uwagę wyżej wymienione czynniki, w przypadku analizy reżimów hybrydalnych warto wyróżnić ich typologie. Proces tworzenia typologii wiąże się z grupowaniem pojęć ze względu na określone kryteria, tj. jeden typ oddziela się od drugiego na podstawie cech je różnicujących, które uwypuklają się w sytuacji poszukiwania podobieństw. Zgodnie z tym, typologia jest kontynuacją klasyfikacji, ponieważ ostatnia rozdziela na grupy różne zjawiska do momentu uzyska- 
nia ich jakościowej jednolitości (Jadow, 1987). Klasyfikacja prezentuje powiązania między klasami pogrupowanych obiektów w celu określenia pozycji obiektów w całym zbiorze, co definiuje jego właściwości. Z kolei typologia ma szersze zastosowanie i pozwala określić właściwości danego zjawiska w odniesieniu do jego pozycji w zbiorze (Szapiro, 1973). Zatem typologia zjawiska pozwala na bardziej szczegółową analizę danego zjawiska.

Rysunek 1. Zależność: klasyfikacja a typologia

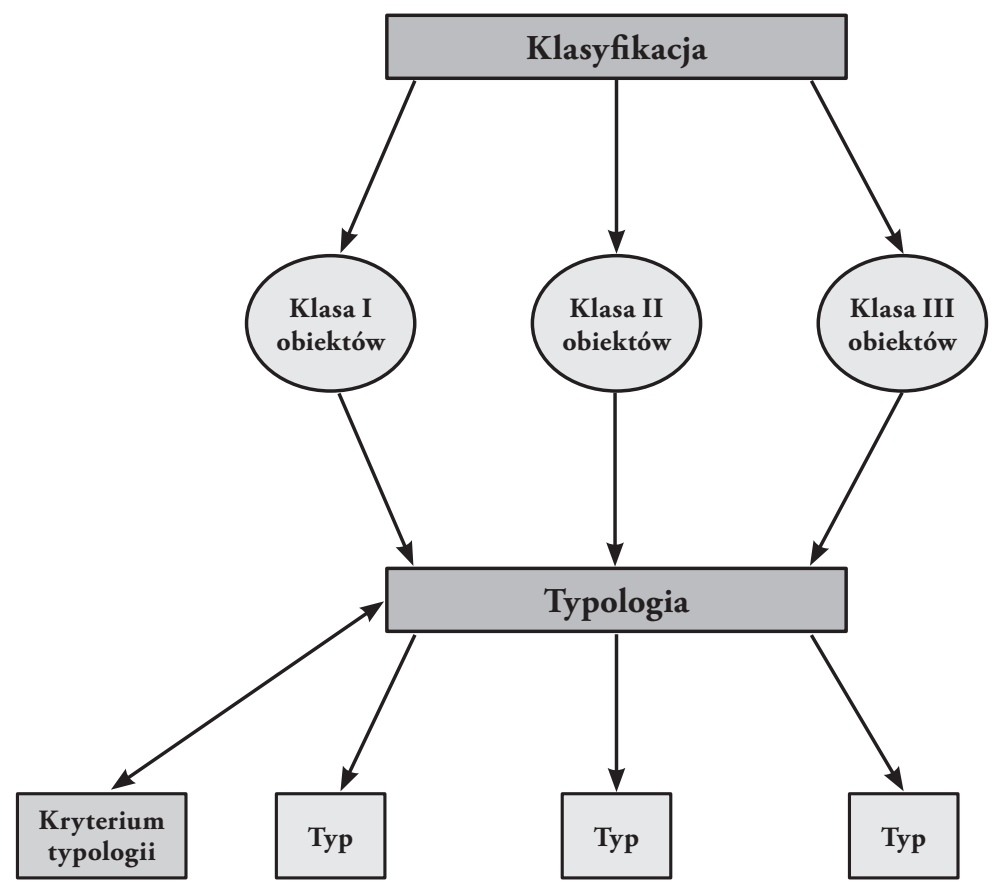

Źródło: opracowanie własne.

Zastosowanie typologii z jednej strony może służyć rekonstrukcji pojęć typologicznych poprzez identyfikację przedmiotów najbardziej zbliżonych do obiektów wzorcowych, czyli typów idealnych. Punktem wyjścia w konstrukcji typologii będzie zatem wskazanie obiektów wzorcowych określonych jako typy modelowe, które nie występują w rzeczywistości (zob. Weber, 1985; 1995). W drugim przypadku tworzenie typologii ma charakter projektujący, a konstrukcja typologii opiera się na przeprowadzonych wcześniej badaniach empirycznych (Nowak, 1970; Nawrot 2012; Rzepiński 2016). Istota typologii sprowadza się nie tylko 
do uzyskania uporządkowanego i syntetycznego obrazu rzeczywistości, ale umożliwia prowadzenie dalszych analiz: porównań osób i zbiorowości, poszukiwania zależności zmiennej typologicznej od innych zmiennych, dokonania opisu oraz wyprowadzenia twierdzeń oceniających i normatywnych (Saran, 2014, s. 24).

Na podstawie przedstawionych założeń dotyczących ujęcia typologii i klasyfikacji można wyodrębnić schemat postępowania, który w dalszej części pracy został zastosowany w celu stworzenia typologii reżimów hybrydalnych. Według tych kryteriów zostały także przyjęte założenia dotyczących tworzenia ilościowej skali pomiarowej jako wzoru dla jakościowej segmentacji przedmiotów (Rzepiński, 2012).

\section{Konstrukcja typologii. Ustalenie schematu typologicznego}

Konstrukcja skali pomiarowej opiera się na trzech wyzwaniach: wyzwaniu konceptualizacji, pomiaru oraz agregacji (zob. Munck, Verkuilen, 2002; Szewczak, 2010; Szewczak, 2012). W bardziej dogłębnej analizie tego procesu możemy wyróżnić następujące etapy: wstępna charakterystyka narzędzia, konceptualizacja teoretyczna, eksplikacja badanego zjawiska, operacjonalizacja zjawiska, formuła agregacji, standaryzacja narzędzia, ocena jakości skali oraz uwzględnienie korekty (Szewczak, 2012). Wiktor Szewczak podkreśla, że w przypadku nominalnej skali pomiarowej poziom konceptualizacji, czyli osadzenia danego indeksu w teorii obejmuje zmienne oraz wyprowadzenie z nich zestawu atrybutów, które przesądzają o trafności utworzonej skali. Na tym etapie istotne jest określenie nadrzędności/podrzędności między poszczególnymi atrybutami (Szewczak 2010; 2012). W przypadku typologii o wiele ważniejszym jest dokonanie opisu każdego ze zjawisk, czyli konceptualizacji teoretycznej badanego zjawiska oraz operacjonalizacji kategorii teoretycznej. Zatem konstrukcje typologii należy rozpocząć od dokonania charakterystyki wyjściowego zestawu cech zjawiska (który na potrzebę tego problemu badawczego określono jako zestaw atrybutów).

Drugie wyzwanie konstrukcji skali pomiarowej obejmuje określenie wskaźników dla przyjętych atrybutów. W przypadku tworzenia typologii drugi etap sprowadzono do weryfikacji wyjściowego zestawu atrybutów poprzez przekształcenie go w atrybuty diagnostycznie, czyli kryteria, na podstawie których dokonano grupowania zjawisk w typy. Proces ten obejmował dobór cech diagnostycznych, które są charakterystyczne dla danego zjawiska, wyodrębnienie cech wspólnych oraz ustalenie ich zależności.

Ostatnie wyzwanie tworzenia skali pomiarowej obejmuje zagregowanie uzyskanych wyników w syntetyczne wskaźniki poprzez wyznaczenie reguł agregacji 
oraz reguł interpretacji. W ujęciu typologii trzeci etap obejmował zgrupowanie wyodrębnionych cech (w pierwszym etapie) na podstawie kryteriów (wyodrębnionych w drugim etapie) w typy. Ze względu na prowadzone badania istotnym było także wyodrębnienie czwartego etapu, który sprowadzony został do swoistej kontroli prawidłowości typologii (walidacji). Etap ten wiąże się z uzasadnieniem rzetelności i trafności typologii, co będzie stanowić o jej walidacji. W sposób ogólny trafność pomiaru oznacza, czy narzędzie mierzy to, co chcieliśmy zmierzyć i z jaką dokładnością to robi (Hornowska, Paluchowski, 2004), oraz to, że pomiar jest wolny od błędów systematycznych i losowych (Arleck, Settle, 1985). Warty podkreślenia jest fakt, że nie istnieje narzędzie całkowicie trafne, ponieważ nie jest możliwe wykluczenie wszystkich czynników zniekształcających trafność pomiaru. Dlatego, zdaniem Franciszka Sztabińskiego, (2011) trafność należy oceniać na podstawie trafności wyniku z innymi właściwymi faktami. Biorąc pod uwagę rodzaje wspomnianych faktów, Claire Selltiz, Lawrence S. Wrightsman, Stuart W. Cook (1977) wyróżniają następujące rodzaje trafności: kryterialną, konstrukcyjną, fasadową lub nominalną, treściową, zewnętrzną, expert validity (ocena ekspertów), known groups validity (porównanie grup o znanych właściwościach). Pierwsza odzwierciedla, czy uzyskane wyniki za pomocą narzędzia potwierdzą się w przypadku użycia innych narzędzi. Trafność konstrukcyjna sprowadza się do weryfikacji, czy dane narzędzie jest właściwe w kontekście używanej teorii. Kolejna wiąże się z oceną logiczną i dotyczy wyobrażeń na temat badanego zjawiska, stosując ją uzyskujemy odpowiedź na pytanie, w jakim stopniu narzędzie mierzy zjawisko. Trafność treściowa (zawartości logicznej lub wewnętrznej) weryfikuje, czy wykorzystane narzędzie pokrywa cały obszar badanego zjawiska. Trafność zewnętrzna sprowadza się do możliwości generalizacji wyników, czyli ich uogólnienia. Oceny trafności expert validity dokonują eksperci, którzy kierują się znajomością przedmiotu oraz intuicją. Trafność known groups validity sprowadza się do zestawienia wyników grup. Zestawia się średnią wyniku grup, mających wysoki i niski wskaźnik cechy, która jest przedmiotem pomiaru z wynikiem grupy docelowej (Selltiz, Wrightsman, Cook, 1977; Sztabiński, 2011).

Drugi wskaźnik stosowany w przypadku walidacji typologii to rzetelność, co przekłada się na dokładność przeprowadzonego pomiaru oraz określenie, czy dany pomiar jest wolny od błędu losowego. W tym przypadku należy wyodrębnić trzy wymiary rzetelności: stabilność rezultatów w czasie zastosowania instrumentu pomiaru, równoważności pomiaru oraz homogeniczności pomiaru. Pierwszy warunek rzetelności sprowadza się do powtórzenia badania w kolejnych okresach. Zestawienie wyników umożliwi potwierdzenie, czy przeprowadzony pomiar był rzetelny. Warto podkreślić, że w tym przypadku dany wynik mogą zniekształ- 
cać trzy czynniki: po pierwsze przerwa między pomiarami; po drugie czynniki zewnętrzne, które mają wpływ na pomiar mogą zniekształcić w różny sposób kolejne pomiary; po trzecie ponowne zastosowanie pomiaru może „wyostrzyć” odporność badanego na narzędzie pomiarowe (Styczeń 1968; Sztabiński 2011). Rzetelność w tym przypadku wymaga spełnienia następujących warunków: przeprowadzania badań w jednakowych odstępach czasu, by wyniki nie mogły ulec zmianom; okres między badaniami powinien być na tyle długi, by na pomiar nie wpływały te same niekontrolowane czynniki; oraz niezależność pomiaru, ponieważ kolejne pomiary nie powinny wpływać wzajemnie na siebie. Równoważność pomiaru z kolei sprowadza się do zastosowania w tym samym czasie wobec tych samych badanych różnych narzędzi badawczych dotyczących tego samego zjawiska. Natomiast homogeniczność ocenia się na podstawie korelacji między dwoma częściami pytań, określa się to mianem zgodności wewnętrznej. W tym przypadku określa się, czy poszczególne pozycje skali mierzą to samo co cała skala (zob. Selltiz, Wrigthsman, Cook, 1977; Fink, 2003, Sztabiński, 2011).

Biorąc pod uwagę proces walidacji stworzonej typologii, zastosowano analizę trafności konstrukcyjnej, która obejmowała weryfikację tego, czy części składowe danej typologii (typy) mieszczą się w ramach teorii badanego zjawiska. Z kolei weryfikacja rzetelności typologii sprowadza się do zestawienia wskaźników (atrybutów) konkretnych typów (wyodrębnionych na podstawie typologii) z wskaźnikami zjawiska, którego dotyczy typologia. Wskaźniki typów muszą być kompatybilne ze wskaźnikami całego zjawiska, czyli muszą być w pewnym stopniu eksplikacją badanego zjawiska. Umożliwia to sprawdzenie, czy dane typy mieszczą się w ramach badanego zjawiska, czyli czy są szczegółowym ujęciem danej kategorii.

Teoretyczne ujęcie zagadnienia typologii oraz zestawienie otrzymanych wyników z procesem konstrukcji skali pomiarowej pozwoliły na wyodrębnienia etapów (schematu konstrukcji typologii), które uznano za istotne w procesie budowy typologii reżimów hybrydalnych. Proces ten został sprowadzony do czterech etapów. Pierwszy obejmuje proces operacjonalizacji typologizowanej kategorii oraz dokonanie jej konceptualizacji (etap wyjaśniający). Drugi etap sprowadzono do diagnostyki cech wyodrębnionych na podstawie konceptualizacji oraz operacjonalizacji, w celu wyodrębnienia kryteriów typologicznych (na podstawie których grupowano typy). Etap trzeci określono jako etap wykonawczy, gdzie na podstawie ustalonych kryteriów dokonano grupowania w typy typologizujące. Ostatni etap posłużył do walidacji uzyskanej typologii. 


\section{Konstrukcja typologii reżimów hybrydalnych}

Dogłębna analiza oraz operacjonalizacja kategorii reżimów hybrydalnych nie jest przedmiotem niniejszej pracy, dlatego podjęto zadanie przedstawienia jedynie zarysu samej tylko kategorii, które wiąże się z pierwszym etapem procesu konstrukcji typologii. Ogólnie tę kategorię sprowadza się do analizy reżimów hybrydalnych przez pryzmat przekształcania się państwa z jednego typu idealnego w drugi. Wiąże się to z balansowaniem na granicy pomiędzy demokracją a autorytaryzmem, kiedy państwo wyzbywa się cech i mechanizmów właściwych dla reżimów autorytarnych jednocześnie adaptując zasady demokratyczne. Nie jest możliwe, aby ten proces odbył się ad hoc, dlatego na pewnym etapie taki reżim posiada mieszankę cech autorytaryzmu i demokracji.

Kategoria reżimów hybrydalnych często jest stosowana w odniesieniu do ewolucji zachodzącej w byłych republikach ZSRR (Robertson, 2011). Wśród badaczy reżimów hybrydalnych należy również wyróżnić Gulermo O’Donnella (1996), Larriego Diamonda (1999) oraz Philippe C. Schmittera (1986) i Terryego L. Karla (1995). Wśród polskich badaczy warto wymienić Andrzeja Antoszewskiego i Ryszarda Herbuta (2006), którzy posługują się pojęciem „szarej strefy” pomiędzy demokracją a autorytaryzmem oraz demokracji delegatywnej, a także Romana Bäckera (2014), który używa terminu reżimów hybrydalnych. Nie sposób wymienić wszystkich zagranicznych badaczy, zajmujących się analizą tego zagadnienia, jednak wśród nich należy wspomnieć m.in. Lucana Waya, Stevena Levitskiego (2010; 2013), Wolfganga Merkla i Andreasa Croissanta (2002), Genadija Szypunowa (2008), Mykole Riabczuka (2009), Dmitrija Furmana (2003), Jana Holzera, Stanislava Balika (2009) i Thomasa Carothersa (2002; 2007). Imponująca liczba i różnorodność ujęć badawczych dotyczących reżimów hybrydalnych spowodowała swoisty problem z jednolitym ujęciem tej kategorii. Badacze używają następujących pojęć: niepełna demokracja, demokracja kierowana, demokracja sterowana, półdemokracja, demokracje delegatywne, demokracje nieliberalne, półautorytarny reżim, konkurencyjny autorytaryzm, szara strefa, reżim kierowanego pluralizmu, reżim dominującej władzy, anokracja. Żadna z powyższych koncepcji nie pozwala jednak na zdefiniowanie reżimów hybrydalnych jako tymczasowego etapu tranzycji systemowej oraz ujęcia poprzez konsolidację hybrydalności reżimu. Analiza wymienionych koncepcji pozwoliła Maryanie Prokop na stworzenie definicji reżimów hybrydalnych, która jest krytyczną syntezą wymienionych powyżej różnorodnych podejść badawczych: „Reżimami hybrydalnymi można określić państwa posiadające cechy istotnościowe zarówno demokracji i autorytaryzmu, to znaczy przez bilans demokratycznych standardów z narzędziami autorytarnymi (w taki 
sposób, że żaden z typów idealnych nie jest w tym przypadku dominującym). Proces ewolucji między antynomicznymi punktami continuum jest długotrwały (i nie doprowadza w konsekwencji do ewolucji w jeden z reżimów politycznych), a także żaden z aktorów uczestniczących w życiu politycznym (organy władzy, naród, organizacje pozarządowe) nie dążą do zmiany systemu drogą rewolucyjnych zmian" (Prokop, 2015a s. 41; 2015b. s. 76).

Definicja ta pozwala na wyróżnienie reżimów hybrydalnych spomiędzy modelowych rozwiązań reżimów politycznych (demokracji, autorytaryzmu i totalitaryzmu), jednak nie pozwala z kolei na określenie, czy dany reżim możemy uznać za etap tranzycji systemowej oraz czy możemy mówić o tym, że dochodzi do konsolidacji cech hybrydalnych. W tym przypadku koniecznym wydaje się stworzenie katalogu kryteriów, które umożliwią ich rozgraniczenie, a zarazem staną się przesłankami umożliwiającymi konstrukcję typologii.

Drugi etap obejmował proces wyodrębnienia kryteriów typologicznych, które posłużyły do zgrupowania zmiennych w typy. Na postawie przyjętej definicji można wyodrębnić dwa kryteria, które determinują czynnik czasowy i czynnik posiadanych cech istotnościowych. Biorąc to pod uwagę, że na trzecim etapie należy zaproponować typy właściwe dla powyższych kryteriów. Istotnym czynnikiem w kontekście realizowanej w państwie tranzycji systemowej było rozgraniczenie, czy mamy do czynienie z etapem tranzycji, czy reżimami, które nie przekształcają się w żadne z modelowych rozwiązań. Kryterium to warto uwzględnić, ponieważ może posłużyć do wyjaśnienia specyfiki postrzegania wieloaspektowości reżimów hybrydalnych. A. Antoszewski i R. Herbut określają reżimy hybrydalne jako swoistą „,zzarą strefę”, zatem jako dowód istnienia państw, które z większym bądź mniejszym trudem pokonują proces przekształcenia z jednego modelowego reżimu politycznego w drugi. Badacze podkreślają, że do takich państw możemy zaliczyć te, w których eksperyment związany z jakościową zmianą reżimu politycznego znacznie się przedłużył lub trwał zbyt krótko (Antoszewski, Herbut, 2001, s. 34-36).

G. O’Donnell, T. Carothers są zgodni wobec tego, że o uplasowaniu państwa wśród reżimów hybrydalnych decydują kryzys społeczno-ekonomiczny oraz ograniczenie pluralizmu politycznego, co wiąże się z brakiem rozwiniętego pluralizmu systemu partyjnego (zob. O’Donnell, 1996; Carothers, 2002). Powyżej wymienione czynniki są niezwykle ważne w kontekście przekształcenia państwa z reżimu autorytarnego w demokratyczny i, o ile kwestie te zostaną z powodzeniem zamienione o demokratyczne odpowiedniki, to adekwatnie szybko państwo przekształci w reżim demokratyczny. Jednakże dostosowanie kwestii wielości i różnorodności systemu partyjnego oraz regulacja kryzysu ekonomicznego wymaga czasu, który 
nie musi doprowadzić do rozwiązania problemu, a wręcz odwrotnie - do jego pogłębienia. Zatem można to określić jako pewnego stopnia hybrydalizację, rozumianą jako konsolidację cech hybrydalnych. Państwo z jednej strony nie dokonuje zmian ustrojowych na rzecz nowego reżimu, z drugiej zaś strony nie następuje cofnięcie się do poprzednich rozwiązań. Zatem w tym przypadku istotnym czynnikiem jest zmienność, którą można sprowadzić do kryterium przekształcenia (czy dochodzi do zmiany reżimy hybrydalnego?), co daje nam podział na reżimy hybrydalne stałe i tymczasowe. W przypadku tych ostatnich mówimy o reżimach hybrydalnych jako etapie tranzycji systemowej, gdy jest to tylko pewien etap pomiędzy wyzbywaniem się cech poprzedniego reżimu a przyjęciem nowego. Na potrzebę artykułu reżim ten jest określony jako hybryda tranzycyjna (przekształcająca się). W przypadku postrzegania reżimów hybrydalnych jako procesu stałego mamy do czynienia z utrwalaniem przejściowych cech reżimu politycznego (które utworzyły się na etapie tranzycji systemowej), przy jednoczesnym zaniechaniu procesu przekształcenia. Ten typ określany jest jako hybryda skonsolidowana (konsolidująca się).

Kolejnym zadaniem jest stworzenie katalogu cech istotnościowych demokracji i autorytaryzmu, który reżim polityczny przyjął, utrwalił i przekształcił. W zależności od bilansu w danym reżimie właściwych cech dla demokracji i autorytaryzmu (spektrum większego oddziaływania) kształtuje się podział na hybrydę demokratyczno-autorytarną oraz hybrydę autorytarno-demokratyczną. W tym przypadku zastosowano kryterium cech istotnościowych.

Amerykańscy badacze L. Way i S. Levicki $(2010 ; 2013)$ postrzegają reżimy hybrydalne poprzez kategorię autorytaryzmu, określając je jako nowy zliberalizowany lub demokratyzowany autorytaryzm. Inni badacze, m.in. G. O'Donnell (1996), T. Carothers (2007), D. Furman (2003), postrzegają reżimy głównie przez pryzmat demokracji (ponieważ uważają, że posiadają one proceduralne minimum demokracji, tj. cykliczne wybory), a z drugiej strony dochodzi tam do regularnych naruszeń wszelkich praw obywatelskich i swobód. Na tej podstawie, biorąc pod uwagę kryterium cech istotnościowych (demokracji i autorytaryzmu), wprowadzonego wcześniej rozgraniczenia na hybrydę demokratyczno-autorytarną (gdy postrzegamy reżim głownie jako dominację dech demokratycznych z tendencjami do rozwiązań niedemokratycznych) oraz hybrydę autorytarno-demokratyczną (gdy mówimy o szeregu naruszeń wszelkich swobód respektowanych w demokracjach z przejawami demokratycznych mechanizmów) warto także wyróżnić trzeci typ danego kryterium, a mianowicie sytuację, gdy bilans cech demokracji i autorytaryzmu będzie współmierny, taki typ jest określany jako hybryda klasyczna. 
Wartym podkreślenia jest także fakt, że między jedną i drugą typologią istnieją ścisłe powiązania. Typologia na podstawie kryterium posiadanych cech jest swoistą prezentacją procesu tranzycji systemowej. Zatem możliwe jest przekształcenie z hybrydy autorytarno-demokratycznej w hybrydę demokratyczno-autorytarną. Z kolei hybryda klasyczna, uwzględniająca pewien bilans cech demokracji i autorytaryzmu, może być postrzegana jako etap przejściowy pomiędzy hybrydą autorytarno-demokratyczną oraz hybrydą demokratyczno-autorytarną. Możliwe jest także przekształcenie hybrydy tranzycyjnej w hybrydę skonsolidowaną pod warunkiem, że nie dochodzi do przekształcenia w jeden z reżimów politycznych (demokracji lub autorytaryzmu), a ma miejsce konsolidacja cech hybrydowych. Podobnie jak jest możliwe przekształcenie hybrydy skonsolidowanej w hybrydę tranzycyjną.

Tabela 1. Typologia reżimów hybrydalnych

\begin{tabular}{|l|c|c|}
\hline $\begin{array}{l}\text { Kryterium } \\
\text { typologizujące }\end{array}$ & \multicolumn{2}{|c|}{ TYPY } \\
\hline $\begin{array}{l}\text { Kryterium } \\
\text { przekształcenia }\end{array}$ & \multicolumn{2}{|c|}{$\begin{array}{c}\text { Hybryda } \\
\text { tranzycyjna }\end{array}$} \\
\hline
\end{tabular}

Źródło: opracowanie własne.

Walidacja stworzonej typologii obejmowała dwa etapy sprawdzenia jej trafności oraz rzetelności. Pierwszy etap dotyczy potwierdzenia, że części składowe typologii mieszczą się w ramach teorii danego zjawiska. Typologia jest oparta na dwóch kryteriach: przekształcenia posiadanych cech, co umożliwiło wyodrębnienie pięciu typów reżimów hybrydalnych (hybryda tranzycyjna, hybryda skonsolidowana, hybryda demokratyczno-autorytarna, hybryda autorytarno-demokratyczna oraz hybryda klasyczna). Proces, według którego wyodrębniono hybrydę tranzycyjną oraz skonsolidowaną, oparto na analizie tranzycji systemowej. Istotna stała się zatem odpowiedź na pytanie, czy reżimy hybrydalne należy postrzegać tylko w oparciu o paradygmat tranzytologiczny (jako etap tranzycji) czy możliwy do wyodrębnienia typ reżimu. Dankwarta Rustow stworzył tzw. „dynamiczny model przejścia", który obejmuje następujące fazy: walkę zróżnicowanych grup 
społecznych, uznanie fundamentalnych zasad demokracji, przystosowanie politycznych elit i społeczeństwa do nowych demokratycznych reguł (Rustow, 1970). Alternatywą jest model zaproponowany przez W. Gelmana, mianowicie „model przejścia z otwartym finałem”, w którym wyróżniono następujące fazy tranzycji: osłabienie poprzedniego reżimu, rozpad poprzedniego reżimu, niezdecydowanie, wyjście z niezdecydowania, co równa się ustanowieniu nowego reżimu oraz konsolidacja nowego reżimu (Gelman, 1999; 2001). Powyższe modele potwierdzają, że etap przejściowy stanowi kumulację cech obu reżimów i to, czy państwo dokona przekształcenia jest uzależnione od sukcesu procesu wyzbycia się starych i przyjęcia nowych mechanizmów. Dlatego wyodrębnienie dwóch typów reżimów hybrydalnych ze względu na kryterium przekształcenia (hybryda tranzycyjna oraz hybryda skonsolidowana) wydaje się uzasadnione.

Uwzględniając drugie kryterium typologii (kryterium posiadanych cech), sprawdzenie jego trafności oparto na analizie cech istotnościowych demokracji i autorytaryzmu posługując się operacjonalizacją kategorii opracowaną przez Davida Helda (demokracja) i Juana J. Linza (autorytaryzm). Cechy istotnościowe dla tychże typów można zestawić antynomicznie, gdyż reżim demokratyczny jest właśnie antynomią reżimu autorytarnego (Held; 2010; Linz, 1995). Dlatego, biorąc pod uwagę ustalenie, że demokracja i autorytaryzm będą skrajnymi punktami continuum, to uzasadnionym wydaje się ulokowanie na linii kolejnych punktów, takich jak hybryda demokratyczno-autorytarna, hybryda autorytarno-demokratyczna oraz hybryda klasyczna.

Rysunek 2. Typologia reżimów hybrydalnych

$$
\text { Hybryda A-D Hybryda klasyczna Hybryda D-A }
$$

Autorytaryzm

Demokracja

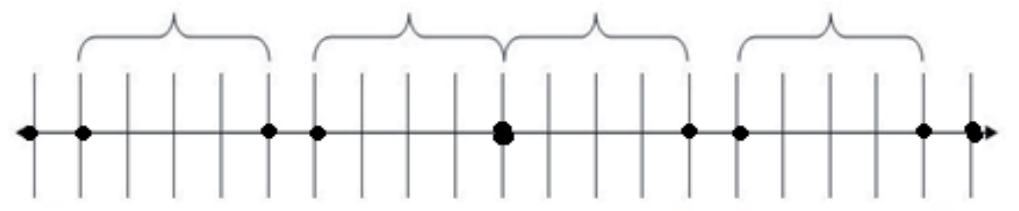

oś continuum

Źródło: opracowanie własne.

Abstrahując od weryfikacji rzetelności typologii, to właśnie zestawienie wskaźników (atrybutów) konkretnych typów (wyodrębnionych na podstawie typologii) ze wskaźnikami zjawiska, którego dotyczy typologizacja, nie jest wymagane. Za- 
danie weryfikacji trafności skali opierało się na osadzeniu typów w teorii badanego zagadnienia. Potwierdziło to, że wyodrębnione w typologizacji typy reżimów hybrydalnych mieszczą się w ramach danego zjawiska. Potwierdzeniem tego są zarówno podjęte działania operacjonalizacji kategorii, jak i ich wzajemna spójność i kompatybilność. Zatem typy te mieszczą się w ramach badanego zjawiska, czyli są szczegółowym ujęciem kategorii.

\section{Podsumowanie}

W prezentowanym artykule podjęto się zaprezentowania teoretycznego i metodologicznego aspektu badań nad reżimami hybrydalnymi, poprzez próbę ich ujęcia za pomocą konstrukcji typologii. Celem artykułu było zbudowanie i zaprezentowanie typologii reżimów hybrydalnych oraz wprowadzenie jasnych kryteriów pozwalających na rozgraniczenia reżimów hybrydalnych jako stanu tymczasowego (kolejny etap tranzycji) lub jako stanu stałego (dokonanie konsolidacji reżimu hybrydalnego).

Tworzenie typologii jest procesem złożonym, który musi być oparty na ustalonych standardach metodologicznych. Dokonano operacjonalizacji pojęcia typologii oraz projekcji schematu jej konstrukcji poprzez zaczerpnięcie założeń z schematu budowy skali pomiarowej. Pozwoliło to na zastosowanie zaprojektowanego schematu w konstrukcji typologii reżimów hybrydalnych.

\section{Bibliografia:}

Alreck, P.L., Seattle, R.B. (1985). The Survey Research Handbook. Homewood: Irwin.

Andreenkowa, W.G., Tolstowoj, J.W. (1982). Typologija i klassifkacija w sociologeczyskih issledowaniah. Moskwa: Nauka.

Antoszewski, A. (2014). Wyboista droga ku demokracji i autorytaryzmowi w świecie postkomunistycznym. Wroctawskie Studia Politologiczne, 16, 7-23.

Antoszewski, A., Herbut, R. (2001). Systemy polityczne wspótczesnego świata. Warszawa: Arche.

Antoszewski, A., Herbut, R. (2007). Systemy polityczne wspótczesnej Europy. Gdańsk: Wydawnictwo Naukowe PWN.

Bäcker, R. (2014). Reżimy hybrydalne. W: J. Juchnowski, R. Wiszniowski (red.), Studia nad wspótczesnymi systemami politycznymi. Podmioty i procesy demokratyczne: ksiega dedykowana profesorowi Andrzejowi Antoszewskiemu (s. 37-46). Toruń: Wydawnictwo Adam Marszałek.

Carothers, T. (2002). The End of Transition Paradigm. Journal of Democracy, 13(2), 5-19. 
Carothers, T. (2007). The "Sequencing” Fallacy. Journal of Democracy, 18(1), 4-25.

Dawydczenko, T.S. (2006). Formuwannja ponjat: „typ”, „typologia” w teorii ta praktyci zurnalistyky, jich sutnist ta wyznachennja. Informacijne suspilstwo, 4, 49-51.

Diamond, L. (1996). Is the Third Wave Over? Journal of Democracy, 7(3), 20-37.

Diamond, L. (1999). Developing Democracy: Toward Consolidation. Baltimore: The Johns Hopkins University Press.

Fink, A. (2003). The Survey Handbook. Thousand Oaks: Sage.

Furman, D. (2003). Politiczwskaja sistema cowremennoj Rpssii i jejo zyznennyj cykl. Swobodnaja myśl, 11, 1-24.

Gelman, W. (1999). Transformacija $w$ Rossii: politichesij rezym i demokraticheskaja opozycija. Moskwa: Moskowskij obszczestwennyj naucznyj fond.

Gelman, W. (2001). Postsowetskie politichesie transformacii. Nasbroski k teorii. Polis, 1, $15-29$.

Held, D. (2010). Modele demokracji. Kraków: Wydawnictwo Uniwersytetu Jagiellońskiego.

Hornowska, E., Paluchowski, W.J. (2004). Kulturowa adaptacja testów psychologicznych. W: J. Brzeziński (red.), Metodologia badań psychologicznych (s. 151-191). Warszawa: Wydawnictwo Naukowe PWN.

Jadow, W.A. (1987). Sociologicheskie issledowanija: metodologia, programma, metody. Moskwa: Nauka.

Kagan, M.S. (1977). Systemnoe passmotrenie osnownych sposobow grupirowky. Filos. i sociol. Issledowanija, 17, 17-25.

Karl, T.L. (1995). The Hybrid Regimes of Central America. Journal of Democracy, 6(3), 72-86.

Kondakow, N.I. (1975). Logiczeskij slowar. Moskwa: Nauka.

Levitsky, S., Way, L.A. (2010). Competitive Authoritarianism. Hybrid Regimes after the Cold War. New York: Cambridge University Press.

Levitsky, S., Way, L.A. (2013). The Durability of Revolutionary Regimes. Journal of Democracy, 24(3), 5-17.

Linz, J.J. (1995). Totalitaryzm i autorytaryzm. W: J. Szczupaczyński (wyb. i oprac.), Wtadza i społeczeństwo. Warszawa: Wydawnictwo Naukowe Scholar, t.1.

Merkel, W., Kruassan, A. (2002). Formalnye i neformalnye instytuty w defektnych demokratijach. Polis, 1-2, 6-17.

Moskwitin, A. (2001). Tipalogija w socialnom poznanii: filosofsko-metodologiczeskij analiz. Wladiwastok: Izd-wo Dalnowostocz.

Munck, G.L., Verkuilen, J. (2002). Conceptualizing and Measuring Democracy: Evaluating Alternative Indices. Comparative Political Studies, 35(1), 7-27.

Nawrot, O. (2012). Wprowadzenie do logiki dla prawników. Warszawa: Wolters Kluwer

Nowak, S. (2007). Metodologia badań socjologicznych. Warszawa: PWN.

O’Donnell, G. (1996). Delegative democracy. Journal of Democracy, 5(1), 55-69.

Pawłowski, T. (1977). Pojęcia i metody wspótczesnej humanistyki. Wrocław, Warszawa, Kraków, Gdańsk: Zakład Narodowy im. Ossolińskich.

Prokop, M. (2015a). Demokratyczno-autorytarna hybryda: redefinicja kategorii teoretycznej. Historia i polityka, 13(20), 31-46. DOI: http://dx.doi.org/10.12775/HiP. 2015.002 . 
Prokop, M. (2015b). Aplikacyjność kategorii alternacji władzy w badaniach nad reżimami hybrydalnymi. Warmińsko-Mazurski Kwartalnik Naukowy. Nauki społeczne, 3(15), 73-87.

Riabczuk, M. (2009). Agony of a "Blackmail State": Rise and (Possible) Fall of Post-Soviet Semi-Authoritarian Regims. W: A.N. Lushyckyj, M. Riabchuk (red.), Ukraine on Its Meandering Path Between East and West (s. 15-40). Bern, Berlin, Bruxelles, Frankfurt am Main, New York, Oxford, Wien: Peter Lang.

Robertson, G.B. (2011). The Politics of Protest in Hybrid Regimes. Managing Dissent in PostCommunist Russia. New York: Cambridge University Press.

Rustow, D.A. (1970). Transition of democracy: Toward a Dynamics. Model Comperative Politics, 2(3), 337-363.

Rzepiński, T. (2016). Konstruowanie typologii i klasyfikacji wielowymiarowych dla potrzeb diagnostyki medycznej. Zagadnienia naukoznawstwa, 2(208), 199-218.

Saran, J. (2014). Klasyfikacje i typologie jako sposoby uprawiania empirycznych badań pedagogicznych. Studia i prace pedagogiczne, 1, 13-30.

Schmitter, P.C., Karl, T.L. (1991). What Democracy Is... and Is Not. Journal of Democracy. (2)3, 77-88.

Selltiz, C., Wrightsman, L.S., Cook, S.W. (1977). Les Mé-thodes de Recherche en Sciences Sociales. Montréal: Les éditions H.R.W.

Styczeń, M. (1968). O trafności i rzetelności testów. W: K. Szaniawski (red.), Metody statystyczne w socjologii. Wybrane zagadnienia. Warszawa: PWN.

Szapiro, S.I. (1973). Ot algoritmow - k suzdenijam. Moskwa: Sow. Radio.

Szewczak, W. (2010). Teoretyczne i metodologiczne podstawy budowy skal demokracji politycznej w politologii porównawczej. Przeglad Politologiczny, 4, 98-108.

Szewczak, W. (2012). Budowanie skali pomiarowej w politologii. Athenaeum. Polskie Studia Politologiczne, 36, 45-68.

Szypunow, G. (2008). Teoretyko-metodologiczni zasady analizu gibrydnych politycznych rezymiw: ukrainskyj kontekst. Polityczni nauky, 3, 89-102.

van Herpen, M.H. (2014). Putinizm. Powolny rozwój radykalnego reżimu prawicowego $w$ Rosji. Gdańsk: Grupa Wydawnicza Harmonia.

Weber, M. (1985). Obiektywność poznania w naukach społecznych. W: A. Chmielecki, S. Czerniak, J. Niżnik, S. Rainko (red.), Problemy socjologii wiedzy (s. 81-88). Warszawa: Państwowe Wydawnictwo Naukowe.

Weber, M. (1995). Szkice z socjologii religii. Warszawa: Książka i Wiedza. 